
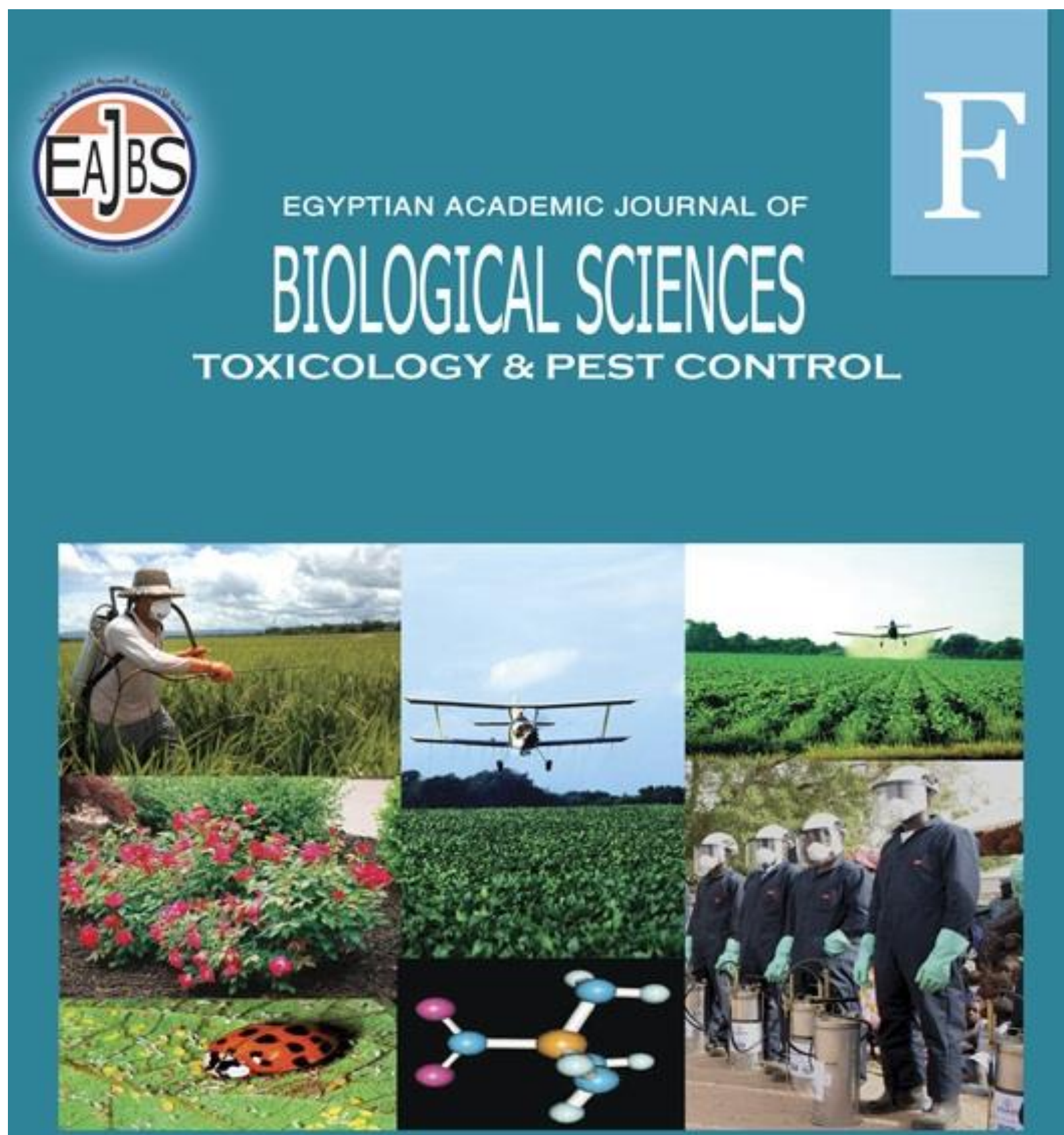

ISSN

2090-0791

WWW.EAJBS.EG.NET

Vol. 13 No. 1 (2021)

$\underline{\text { www.eajbs.eg.net }}$

Citation :Egypt. Acad. J. Biolog. Sci. (F. Toxicology \& Pest control) Vol.13(1)pp1-14 (2021) DOI: 10.21608/EAJBSF.2021.138339 
Egypt. Acad. J. Biolog. Sci., 13(1):1- 14(2021)

Egyptian Academic Journal of Biological Sciences
F. Toxicology \& Pest Control
ISSN: 2090 - 0791
http://eajbsf.journals.ekb.eg/

\title{
Efficiency of Certain Herbicides and Adjuvants Combinations Against Weeds in Wheat Fields
}

\author{
Sameh S. A. Hamouda, Mohamed F. El-Tawil, Emad M. A. Marzouk, and \\ Hassan M. S. Khalifa \\ Plant Protection Department, Faculty of Agriculture, Al-Azhar University, Nasr city, \\ Cairo, Egypt. \\ *E-Mail : samehs.a.hamouda@ gmail.com
}

\section{ARTICLEINFO}

Article History

Received: 10/11/2020

Accepted: 11/1/2020

\section{Keywords:}

Wheat, weed control, adjuvants, herbicides, weeds, grain yield

\section{ABSTRACT}

Two field experiments were carried out at El-Dalangat district, ElBeheira Governorate, Egypt during two successive winter seasons of 20172018 and 2018-2019, to evaluate the efficiency of post-emergence herbicides: Clodimex (clodinafop-propargyl 24\% EC), Pallas (pyroxsulam 4.5\% OD), Skylla (tribenuron-methyl $75 \% \mathrm{WG}$ ) at their recommended rates or at reduced rates without adjuvants or in combination with Argal at $0.2 \% \mathrm{v} / \mathrm{v}$ and Techno oil at $0.3 \% \mathrm{v} / \mathrm{v}$ adjuvants, tank mixture of clodinafop-propargyl + tribenuronmethyl at half recommended rate combined with Argal or Techno oil adjuvants and hand weeding at 25 and 40 days after sowing (DAS) for controlling predominant weeds in wheat crop compared to unweeded check. The results indicated that the dominant weed species in the experimental wheat field were, two grassy weeds, Phalaris minor and Eragrostis ciliagensis, and six broadleaved weeds: Malva parviflora, Sonchus oleraceus, Coronopus squamatus, Rumex dentatus, Anagallis arvensis and Medicago polymorpha during the both seasons. In addition, Eclipta alba weed was found only in the second season. Results also showed that all herbicidal treatments significantly decreased the total weed biomass compared to the unweeded check 60 and 90 DAS. Among herbicidal treatments applied, pyroxsulam herbicide at $3 / 4$ of recommended rate with Argal recorded the highest weed control efficiency against grassy and broad-leaved weeds followed by pyroxsulam treated plots at $3 / 4$ of recommended rate combined with Techno oil 60 and 90 DAS throughout the two studied seasons. On the other hand, regardless of application rates or adjuvants, tribenuron-methyl and clodinafop-propargyl seemed to be the least effective treatments against the total weeds 60 and 90 DAS during the both seasons in comparison with unweeded plots. The maximum increase in wheat grain yield was observed in pyroxsulam treated plots at $3 / 4$ recommended rate with Argal or Techno oil combinations. It could be concluded that the addition of Argal or Techno oil to herbicides spray solutions at reduced rates especially at $3 / 4$ of the recommended rate resulted in enhancing the herbicidal activity against weeds and increasing wheat grain yield.

\section{INTRODUCTION}

Wheat (Triticum aestivum L.) is one of the most important cereal winter crops in Egypt and considers a key component of global food security. It is used as a staple food grain for 
urban and rural societies, and its straw is used as a major animal feed. Wheat contributes more calories and proteins to the world diet than any other cereal crops (Abd-El-Haleem et al., 1998; Adams et al., 2002; and Shewry, 2009).

Weeds are the most noxious pests among yield-limiting constraints. Estimates reveal that more than one-third of the total field losses due to biotic stresses are caused by weeds alone which often go unnoticed due to their multipronged hidden effects on plant growth (Sharma et al., 2016). Weeds compete with wheat for resources and can impose a huge loss of quantity and quality of wheat yield (Khaliq et al., 2011). Moreover, Soliman and Hamza (2015) reported that weeds are the most important problem in wheat production which causes a high loss in the crop. It can reduce grain yield by 42 to 56\% (Abdel-Hamid et al., 1998 and Abouziena et al., 2008). Likewise, uncontrolled weeds caused up to $66 \%$ reduction in wheat grain yield (Kumar et al., 2009 and Kumar et al., 2011) or even more depending upon the weed density, type of weed flora and duration of infestations.

Losses due to weeds can be managed by different approaches such as manual, mechanical, allelopathic, biological and chemical methods. Among various weed management strategies, chemical weed control is considered the most effective and economical method to manage weeds in wheat (Javaid et al., 2020). In addition, the optimum rate and suitable combination of herbicide with adjuvants play a vital role in controlling weeds at an acceptable level and produce maximum crop yield, as well as minimizing environmental pollution.

Therefore, the main objective of the present research was to determine the effect of adjuvants in increasing the effectiveness of certain post-emergence herbicides against the dominant weed species with the lowest possible cost without affecting the yield of wheat.

\section{MATERIALS AND METHODS}

\section{Experimental Site:}

The field experiments were carried out at El-Dalangat district, El-Beheira Governorate, Egypt during two successive winter seasons of 2017-2018 and 2018-2019.

\section{Sowing Date:}

Seeds of wheat (cv. Gemeza-11) were sown on $12^{\text {th }}$ and $18^{\text {th }}$ November at the recommended rate $\left(60 \mathrm{~kg} \mathrm{fed}^{-1}\right)$ during the growing winter 2017-2018 and 2018-2019 seasons, respectively.

\section{Experimental Design:}

Efficacy of post-emergence herbicides i.e., Clodimex (clodinafop-propargyl 24\% EC), Pallas (pyroxsulam 4.5\% OD), Skylla (tribenuron-methyl 75\% WG) at their recommended rates or at reduced rates without adjuvant or in combination with Argal (organosilicone) at $0.2 \% \mathrm{v} / \mathrm{v}$ or Techno oil (botanical source) at $0.3 \% \mathrm{v} / \mathrm{v}$ adjuvants, tank mixture of clodinafoppropargyl + tribenuron-methyl at half recommended rates combined with Argal or Techno oil adjuvants and hand weeding at 25 and 40 days after sowing (DAS) were evaluated in the wheat field compared to the weedy check. The herbicidal treatments, rates and time of application are shown in Table (1). The experiments were arranged in a randomized complete block design (RCBD) with three replicates for each treatment, with plot area of 21 $\mathrm{m}^{2}$ (7.0 m length and $3.0 \mathrm{~m}$ width). All tested herbicides with or without adjuvants were applied at 30 DAS using a 5-litres knapsack sprayer (Gloria Hoppy No. 299 TS.) at 200 L water fed. ${ }^{-1}$. The mixture of herbicides and adjuvants was tank-mixed immediately before application. However, hand weeding treatment was done twice at 25 and 40 DAS. 
Table 1: Herbicidal treatments, rates and time of application during 2017-2018 and 20182019 winter seasons.

\begin{tabular}{|c|c|c|}
\hline Treatments & Rates of application fed. ${ }^{-1}$ & $\begin{array}{c}\text { Time of } \\
\text { application }\end{array}$ \\
\hline Clodinafop-propargyl & $52.50 \mathrm{ml}$ ( $1 / 2$ recommended rate $)$ & \multirow{7}{*}{$\begin{array}{l}\text { POST } \\
\text { 30 DAS }\end{array}$} \\
\hline Clodinafop-propargyl & $78.75 \mathrm{ml}$ ( $3 / 4$ recommended rate $)$ & \\
\hline Clodinafop-propargyl & $105 \mathrm{ml}$ (recommended rate) & \\
\hline Clodinafop-propargyl $+\mathrm{A}^{*}$ & $52.50 \mathrm{ml}+0.2 \%$ & \\
\hline Clodinafop-propargyl + A & $78.75 \mathrm{ml}+0.2 \%$ & \\
\hline Clodinafop-propargyl $+\mathrm{TO}^{* *}$ & $52.50 \mathrm{ml}+0.3 \%$ & \\
\hline Clodinafop-propargyl +TO & $78.75 \mathrm{ml}+0.3 \%$ & \\
\hline Pyroxsulam & $80 \mathrm{ml}$ (1/2 recommended rate $)$ & \multirow{7}{*}{$\begin{array}{l}\text { POST } \\
30 \text { DAS }\end{array}$} \\
\hline Pyroxsulam & $120 \mathrm{ml}$ ( $3 / 4$ recommended rate $)$ & \\
\hline Pyroxsulam & $160 \mathrm{ml}$ (recommended rate) & \\
\hline Pyroxsulam + A & $80 \mathrm{ml}+0.2 \%$ & \\
\hline Pyroxsulam + A & $120 \mathrm{ml}+0.2 \%$ & \\
\hline Pyroxsulam +TO & $80 \mathrm{ml}+0.3 \%$ & \\
\hline Pyroxsulam +TO & $120 \mathrm{ml}+0.3 \%$ & \\
\hline Tribenuron-methyl & $4 \mathrm{~g}$ (1/2 recommended rate) & \multirow{7}{*}{$\begin{array}{l}\text { POST } \\
\text { 30 DAS }\end{array}$} \\
\hline Tribenuron-methyl & $6 \mathrm{~g}$ (3/4 recommended rate $)$ & \\
\hline Tribenuron-methyl & $8 \mathrm{~g}$ (recommended rate) & \\
\hline Tribenuron-methyl + A & $4 \mathrm{~g}+0.2 \%$ & \\
\hline Tribenuron-methyl + A & $6 \mathrm{~g}+0.2 \%$ & \\
\hline Tribenuron-methyl $+\mathrm{TO}$ & $4 \mathrm{~g}+0.3 \%$ & \\
\hline Tribenuron-methyl +TO & $6 \mathrm{~g}+0.3 \%$ & \\
\hline $\begin{array}{l}\text { Clodinafop-propargyl } \\
+ \text { Tribenuro-methyl }\end{array}$ & $\begin{array}{l}52.50 \mathrm{ml}+4 \mathrm{~g}(1 / 2 \text { recommended } \\
\text { rate })\end{array}$ & \multirow{3}{*}{$\begin{array}{l}\text { POST } \\
\text { 30 DAS }\end{array}$} \\
\hline $\begin{array}{l}\text { Clodinafop-propargyl } \\
+ \text { Tribenuro-methyl }+\mathrm{A}\end{array}$ & $52.50 \mathrm{ml}+4 \mathrm{~g}+0.2 \%$ & \\
\hline $\begin{array}{l}\text { Clodinafop-propargyl } \\
+ \text { Tribenuro-methyl }+\mathrm{TO}\end{array}$ & $52.50 \mathrm{ml}+4 \mathrm{~g}+0.3 \%$ & \\
\hline Handweeding & Twice & 25 and $40 \mathrm{DAS}$ \\
\hline Weedy check & --- & --- \\
\hline
\end{tabular}

$* \mathrm{~A}=$ Argal, $\quad * * \mathrm{TO}=$ Techno oil.

\section{Treatments Evaluation:}

The crop was kept under constant observation from sowing till harvest. Weeds in one square meter were collected using a quadrate of $50 \mathrm{~cm} \times 50 \mathrm{~cm}$ placed at 4 randomly selected spots in each experimental plot at 30 and 60 days after treatment (DAT). Then identified, weighed $\left(\mathrm{g} \mathrm{m}^{-2}\right)$ and classified by (Zaki, 2000), and weed biomass percentage was determined using the following formula:

$$
\text { Weed biomass } \%=\frac{\text { average fresh weight of each weed }}{\text { average fresh weight of total weed }} \times 100
$$

Weed control efficiency (WCE) was also calculated according to (Mani et al., 1973) using the following formula:

$$
\text { WCE } \%=\frac{\text { FWC }- \text { FWT }}{\text { FWC }} \times 100
$$

Where:

$\mathrm{FWC}=$ mean fresh weight of weeds in weedy plots.

FWT $=$ mean fresh weight of weeds in treated plots. 


\section{Yield Evaluation:}

At maturity, wheat plants were harvested manually, air-dried for three days, then, the following characters were recorded. Grain yield (ardab fed. ${ }^{-1}$ ) and 1000-grain weight $(\mathrm{g})$ were recorded. The increase percent (I \%) in wheat grain yield was recorded after adjusting moisture to $14 \%$ level and calculated using the following formula:

Where:

$$
\% \text { increase }=\frac{\mathrm{T}-C}{\mathrm{~T}} \times 100
$$

$$
\begin{aligned}
& \mathrm{T}=\text { Mean grain yield of wheat in the treated plots. } \\
& \mathrm{C}=\text { Mean grain yield of wheat in the untreated plots. }
\end{aligned}
$$

The straw yield of wheat as ton fed. ${ }^{-1}$ was determined by weighing the biological yield in each plot then subtracting the grain weight from the biological yield. However, the harvest index $(\mathrm{HI})$ was calculated using the following formula:

\section{Statistical Analysis:}

$$
\mathrm{HI}(\%)=\frac{\text { Grain yield }}{\text { Biological yield }} \times 100
$$

The data were subjected to analysis of variance (ANOVA) according to Gomez and Gomez (1984). Means were compared using Fisher's test and Least Significant Difference (LSD) was determined at 0.05 probability level.

\section{RESULTS AND DISCUSSION}

\section{Dominant Weed Species:}

Data illustrated in Fig. (1) indicated that weed species associated with wheat plants during 2017-2018 and 2018-2019 seasons were: Phalaris minor and Eragrostis ciliagensis, as grassy weeds, while broad-leaved weeds were: Malva parviflora, Sonchus oleraceus, Coronopus squamatus, Rumex dentatus, Anagallis arvensis, Medicago polymorpha and Eclipta alba. However, Eclipta alba was found in the second season only. Broad-leaved weeds were the most dominant than grassy weeds in the experimental site during the both studied seasons. Among broad-leaved weeds, Coronopus squamatus and Malva parviflora were the most dominant. Similar findings are reported by Mukherjee et al. (2015); Sharma et al. (2018) and Chhokar et al. (2019). Likewise, these findings are in conformity with Mahmoud et al. (2016) who reported that the wheat fields was infested with both grassy and broad-leaved weeds. The dominant broad-leaved weeds in El-Beheira and Alexandria were Beta vulgaris, Malva parviflora, Medicago polymorpha, Sonchus oleraceus, Anagallis arvensis and Coronopus squamatus, while the dominant grassy weed was Phalaris minor.

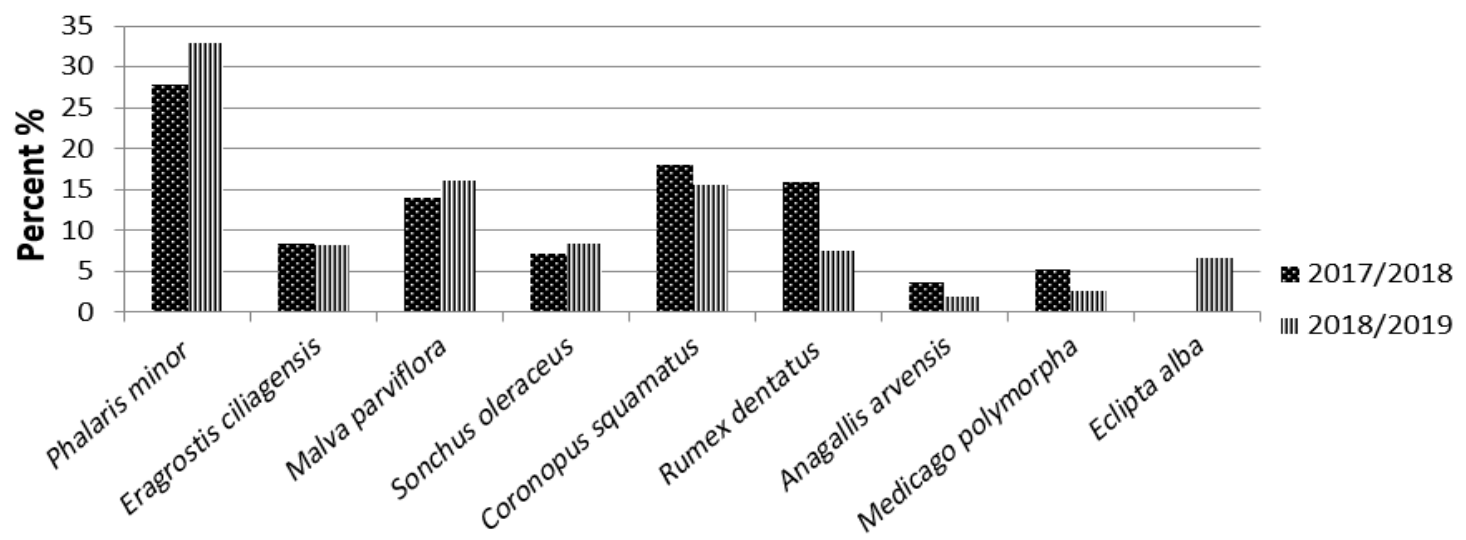

Fig. 1: Weed flora in wheat field during 2017-2018 and 2018-2019 seasons 


\section{Effect of Herbicidal Treatments on Weed Biomass:}

The efficiency of herbicides with or without adjuvants and hand weeding in controlling predominant weeds in the wheat fields during 2017-2018 and 2018-2019 winter seasons 60 and 90 DAS are shown in Tables (2 and 3). Obtained results elucidated that all herbicidal treatments were significantly $(P=0.05)$ effective in controlling weeds, resulting in less fresh weight of weeds and higher weed control efficiency compared to unweeded check.

\section{Effect of Herbicidal Treatments on Grassy Weeds:}

Concerning the recommended rate, data presented in Tables (2 and 3) indicated that clodinafop-propargyl followed by pyroxsulam were the most effective treatments in controlling grassy weeds 60 and 90 DAS during both studied seasons over the unweeded check. They gave 96.25 and $92.83 \%$ and 95.54 and $90.25 \%$ WCE 90 DAS in the first and second seasons, respectively. On contrary, tribenuron-methyl recorded poor grassy weed control 60 and 90 DAS during the two studied seasons. The herbicidal activities of tribenuron-methyl were 28.10 and 26.82 \% WCE during 2017-2018 season, and 23.19 and 24.22\% WCE during 2018-2019 season, 60 and 90 DAS, respectively.

Clodinafop-propargyl and pyroxsulam at $3 / 4$ of the recommended rate showed satisfactory control of grassy weeds, which gave 83.77 and $76.09 \%$ WCE, respectively, 90 DAS in the first season. Moreover, the two previous herbicides at half of the recommended rate showed a moderate control of grassy weeds, which resulted in 68.49 and $62.61 \%$ WCE, respectively 90 DAS in the first season. The same trend was found in the second season. Also, the tank mixture of clodinafop-propargyl + tribenuron-methyl at half of the recommended rate showed a moderate control of grassy weeds 60 and 90 DAS throughout the two studied seasons.

Regarding reduced rates of tested herbicides combined with Argal and Techno oil, it is significantly increased the activity of clodinafop-propargyl, pyroxsulam and tank mix of clodinafop-propargyl + tribenuron-methyl (Tables 2 and 3). Evidently, clodinafop-propargyl and pyroxsulam when used either at half or $3 / 4$ of recommended rates plus adjuvants significantly showed better control of annual grassy weeds, as compared to the low rates alone. Further, these treatments significantly showed similar activity to the recommended rate without adjuvants, which better than hand weeding treatment.

The highest decrease in total grassy weeds was achieved by clodinafop-propargyl treated plots at $3 / 4$ of recommended rates with either Argal or Techno oil adjuvants, followed by pyroxsulam at $3 / 4$ of recommended rate with Argal, clodinafop-propargyl at the recommended rate without adjuvants, and clodinafop-propargyl + tribenuron-methyl at half of recommended rate tank mix with Argal 60 and 90 DAS during the two studied seasons. These treatments were very effective in controlling grassy weeds compared to unweeded check, they gave 100, 98.56, 98.52, 96.25 and 94.51\% WCE in the first season, and 99.29, 98.45, 96.30, 95.54 and 92.56\% WCE in the second season, respectively, at 90 DAS. On contrary, regardless of application rate and used adjuvants, tribenuron-methyl recorded minimum weed control efficiency against grassy weeds when compared to weedy check during the two tested seasons.

\section{Effect of Herbicidal Treatments on Broad-Leaved Weeds:}

Data listed in Tables (2 and 3) demonstrated that pyroxsulam followed by tribenuron-methyl were the most effective treatments in reducing broad-leaved weeds populations resulting in the lowest biomass of weeds due to its higher weed control efficiency compared to unweeded check 60 and 90 DAS during 2017-2018 and 2018-2019 seasons. They gave 94.63 and $92.27 \%$ WCE in the first season and 93.35 and $90.49 \%$ WCE in the second season, respectively, 90 DAS. On contrary, clodinafop-propargyl recorded poor broad-leaved weed control 60 and 90 DAS during the two studied seasons. It gave 38.91 
and 36.44 \% WCE during 2017-2018 season, and 34.49 and 32.27\% WCE during 2018-2019 season, 60 and 90 DAS, respectively. In addition, pyroxsulam and tribenuron-methyl at $3 / 4$ of recommended rates showed satisfactory control of broad-leaved weeds, they gave 81.42 and $77.18 \%$ WCE, respectively, 90 DAS in the first season. However, at their half recommended rate without adjuvants showed a moderate control of broad-leaved weeds 67.60 and $63.60 \%$ WCE, respectively, 90 DAS in the first season. These results are in line with Mukherjee et al. (2015) who revealed that there was a significant reduction in weed populations and dry matter accumulation due to tribenuron-methyl application at a higher dose $\left(45.0 \mathrm{~g} \mathrm{ha}^{-1}\right)$ compared to a lower dose $\left(22.5 \mathrm{~g} \mathrm{ha}^{-1}\right)$. Also, clodinafop-propargyl + tribenuron-methyl at half of the recommended rate without adjuvants showed a moderate control of broad-leaved weeds 60 and 90 DAS in both seasons.

Regarding reduced rates of tested herbicides with Argal or Techno oil, data illustrated in Tables ( 2 and 3 ) indicate that addition of Argal or Techno oil adjuvants to pyroxsulam, tribenuron- methyl and clodinafop-propargyl + tribenuron-methyl spray solutions significantly increased their activities when used at reduced rates. Pyroxsulam and tribenuron-methyl when used either at half or at $3 / 4$ of the recommended rate with adjuvants significantly showed better control of annual broad-leaved weeds, as compared to the reduced rates without adjuvants, and significantly showed similar activity to those obtained with the recommended rate.

In this respect, pyroxsulam and tribenuron-methyl at $3 / 4$ of recommended rate combined with Argal resulted in the lowest fresh weight of the total broad-leaved weeds and maximum weed control efficiency 60 and 90 DAS during the both years, followed by the same treatments combined with Techno oil, pyroxsulam and tribenuron-methyl at recommended rates without adjuvants and tank mix of clodinafop-propargyl + tribenuronmethyl with Argal adjuvant. These treatments reduced fresh weight of broad-leaved weeds by $98.87,98.44,96.04,95.85,94.63,92.27$ and $89.86 \%$ WCE in the first season, and 98.22, 97.49, 94.70, 93.38, 93.35, 90.49 and $88.23 \%$ WCE in the second season, respectively, 90 DAS compared to unweeded check. In addition, clodinafop-propargyl with or without adjuvants showed poor performance and minimum WCE against broad-leaved weeds $>44 \%$ compared to untreated plots during the two application seasons.

\section{Effect of Herbicidal Treatments on Total Weeds:}

It is obvious that all weed control treatments gave a significant decrease in fresh weight of the total weeds 60 and 90 DAS compared to unweeded check (Tables 2 and 3). However, the weeded treatments differed in their efficiency in weed suppression. In this respect, regardless of application rates or adjuvants, the highest efficiency of treatments on total weeds (grassy and broad-leaved weeds) was recorded in pyroxsulam and a mixture of clodinafop-propargyl + tribenuron-methyl. However, pyroxsulam at $3 / 4$ of recommended rate with Argal recorded the highest weed control efficiency against the grassy and broad-leaved weeds followed by pyroxsulam at $3 / 4$ of recommended rate combined with Techno oil, pyroxsulam at the recommended rate without adjuvants, tank mix of clodinafop-propargyl + tribenuron-methyl combined with Argal and pyroxsulam at half of the recommended rate with Argal treatments 60 and 90 DAS throughout the two studied seasons. These treatments reduced the total fresh weight of weeds by $98.74,95.47,93.98,91.54$ and $86.47 \%$ WCE and 97.43, 93.61, 92.07, 90.01 and 83.83\% WCE during the first and second season, respectively, 90 DAS compared to control.

On the other side, hand weeding seemed to be a moderately effective treatment against grassy and broad-leaved weeds, it gave 73.58 and $68.71 \%$ WCE in the first season and 69.29 and $65.83 \%$ in the second season 60 and 90 DAS, respectively. Moreover, regardless of application rates or adjuvants, the results showed that tribenuron-methyl and clodinafop- 
propargyl seemed to be the least effective treatments against total weeds 60 and 90 DAS during the both seasons in comparison with unweeded plots.

Table 2: Effect of herbicidal treatments on weed biomass $\left(\mathrm{g} \mathrm{m}^{-2}\right)$ in wheat crop 60 and 90 DAS in 2017-2018 winter season.

\begin{tabular}{|c|c|c|c|c|c|c|c|c|c|c|c|c|c|}
\hline \multirow[b]{2}{*}{ Treatments } & \multirow{2}{*}{ Rate fed..$^{-1}$} & \multicolumn{6}{|c|}{ 60 DAS } & \multicolumn{6}{|c|}{90 DAS } \\
\hline & & $\begin{array}{c}\text { Mean weed } \\
\text { biomass } \\
\left(\mathrm{g} \cdot \mathrm{m}^{-2}\right)\end{array}$ & WCE & $\begin{array}{c}\text { Mean weed } \\
\text { biomass } \\
\left(\mathrm{g} \cdot \mathrm{m}^{-2}\right)\end{array}$ & WCE & $\begin{array}{c}\text { Mean weed } \\
\text { biomass } \\
\left(\mathrm{g} \cdot \mathrm{m}^{-2}\right)\end{array}$ & WCE & $\begin{array}{c}\text { Mean weed } \\
\text { biomass } \\
\left(\mathrm{g} \cdot \mathrm{m}^{-2}\right)\end{array}$ & WCE & $\begin{array}{c}\text { Mean weed } \\
\text { biomass } \\
\left(\mathrm{g} \cdot \mathrm{m}^{-2}\right)\end{array}$ & WCE & $\begin{array}{c}\text { Mean weed } \\
\text { biomass } \\
\left(\mathrm{g} . \mathrm{m}^{-2}\right)\end{array}$ & WCE \\
\hline Clodinafop-propargyl & $105 \mathrm{ml}$ & 5.90 & 97.09 & 220.07 & 38.91 & 225.97 & 59.86 & 10.60 & 96.25 & 316.67 & 36.44 & 327.27 & 58.07 \\
\hline Clodinafop-propargyl $+\mathrm{A}^{*}$ & $52.5 \mathrm{ml}+0.2 \%$ & 11.73 & 94.21 & 225.83 & 37.31 & 237.57 & 57.80 & 19.40 & 93.13 & 326.63 & 34.44 & 346.03 & 55.67 \\
\hline Clodinafop-propargyl + A & $78.75 \mathrm{ml}+0.2 \%$ & 0.00 & 100.00 & 203.03 & 43.64 & 203.03 & 63.94 & 0.00 & 100.00 & 292.63 & 41.26 & 292.63 & 62.51 \\
\hline Clodinafop-propargyl $+\mathrm{TO}^{* *}$ & $52.5 \mathrm{ml}+0.3 \%$ & 20.93 & 89.67 & 239.27 & 33.58 & 260.20 & 53.78 & 35.73 & 87.35 & 346.97 & 30.36 & 382.70 & 50.97 \\
\hline Pyroxsulam & $120 \mathrm{ml}$ & 46.63 & 77.00 & 56.53 & 84.31 & 103.17 & 81.67 & 67.50 & 76.09 & 92.57 & 81.42 & 160.07 & 79.49 \\
\hline Pyroxsulam & $160 \mathrm{ml}$ & 12.20 & 93.98 & 16.33 & 95.47 & 28.53 & 94.93 & 20.23 & 92.83 & 26.73 & 94.63 & 46.97 & 93.98 \\
\hline Pyroxsulam $+\mathrm{A}$ & $80 \mathrm{ml}+0.2 \%$ & 25.53 & 87.41 & 35.57 & 90.13 & 61.10 & 89.15 & 41.07 & 85.46 & 64.53 & 87.05 & 105.60 & 86.47 \\
\hline Pyroxsulam + A & $120 \mathrm{ml}+0.2 \%$ & 1.23 & 99.39 & 0.73 & 99.80 & 1.97 & 99.65 & 4.17 & 98.52 & 5.63 & 98.87 & 9.80 & 98.74 \\
\hline Pyroxsulam +TO & $80 \mathrm{ml}+0.3 \%$ & 41.27 & 79.64 & 73.83 & 79.50 & 115.10 & 79.56 & 60.57 & 78.55 & 103.17 & 79.29 & 163.73 & 79.02 \\
\hline Pyroxsulam +TO & $120 \mathrm{ml}+0.3 \%$ & 11.40 & 94.38 & 15.03 & 95.83 & 26.43 & 95.30 & 15.60 & 94.48 & 19.73 & 96.04 & 35.33 & 95.47 \\
\hline Tribenurin-methyl & $4 \mathrm{~g}$ & 158.13 & 22.00 & 123.60 & 65.69 & 281.73 & 49.96 & 229.10 & 18.86 & 181.37 & 63.60 & 410.47 & 47.41 \\
\hline Tribenurin-methyl & $6 \mathrm{~g}$ & 148.03 & 26.98 & 76.13 & 78.87 & 224.17 & 60.18 & 213.63 & 24.34 & 113.67 & 77.18 & 327.30 & 58.07 \\
\hline $\begin{array}{l}\text { Clodinafop-propargyl } \\
+ \text { tribenurin-methyl }\end{array}$ & $52.5 \mathrm{ml}+4 \mathrm{~g}$ & 54.10 & 73.31 & 111.57 & 69.03 & 165.67 & 70.57 & 77.13 & 72.68 & 161.27 & 67.63 & 238.40 & 69.46 \\
\hline $\begin{array}{l}\text { Clodinafop-propargyl + } \\
\text { tribenurin-methyl } \quad+\text { A }\end{array}$ & $\begin{array}{l}52.5 \mathrm{ml}+4 \mathrm{~g} \\
+0.2 \% \\
\end{array}$ & 10.07 & 95.03 & 31.70 & 91.20 & 41.77 & 92.58 & 15.50 & 94.51 & 50.53 & 89.86 & 66.03 & 91.54 \\
\hline $\begin{array}{l}\text { Clodinafop-propargyl }+ \\
\text { tribenurin-methyl }+ \text { TO }\end{array}$ & $\begin{array}{l}52.5 \mathrm{ml}+4 \mathrm{~g} \\
+0.3 \% \\
\end{array}$ & 24.00 & 88.16 & 57.83 & 83.95 & 81.83 & 85.46 & 38.50 & 86.37 & 86.37 & 82.66 & 124.87 & 84.00 \\
\hline Handweeding & Twice & 70.43 & 65.26 & 78.30 & 78.26 & 148.73 & 73.58 & 109.60 & 61.19 & 134.63 & 72.98 & 244.23 & 68.71 \\
\hline $\begin{array}{l}\text { Weedy check } \\
\end{array}$ & $-\ldots$ & 202.73 & 0.00 & 360.24 & 0.00 & 562.98 & 0.00 & 282.37 & 0.00 & 498.20 & 0.00 & 780.57 & 0.00 \\
\hline LSD at $5 \%(1)$ & & 32.08 & & 33.36 & & 50.56 & & 36.61 & & 50.32 & & 71.74 & \\
\hline L.S.D at $5 \%(2)$ & & 28.86 & & 34.02 & & 49.53 & & 34.58 & & 48.29 & & 66.17 & \\
\hline
\end{tabular}

$\mathrm{A}^{*}=$ Argal at $0.2 \%$ v.v. $\quad-\mathrm{TO}^{* *}=$ Techno oil at $0.3 \%$ v.v. $-\quad \mathrm{WCE}=$ weed control efficiency

(1): L.S.D. of treatments including unweeded control. - (2): L.S.D: of treatments without unweeded control.

Table 3: Effect of herbicidal treatments on weed biomass $\left(\mathrm{g} \mathrm{m}^{-2}\right)$ in wheat crop 60 and 90 DAS in 2018-2019 winter season.

\begin{tabular}{|c|c|c|c|c|c|c|c|c|c|c|c|c|c|}
\hline \multirow[b]{3}{*}{ Treatments } & \multirow[b]{3}{*}{ Rate fed..$^{-1}$} & \multicolumn{6}{|c|}{60 DAS } & \multicolumn{6}{|c|}{90 DAS } \\
\hline & & \multicolumn{2}{|c|}{ grassy weeds } & \multicolumn{2}{|c|}{ broad-leaved weeds } & \multicolumn{2}{|c|}{ Total weeds } & \multicolumn{2}{|c|}{ grassy weeds } & \multicolumn{2}{|c|}{ broad leaved weeds } & \multicolumn{2}{|c|}{ Total weeds } \\
\hline & & $\begin{array}{c}\text { Mean weed } \\
\text { biomass } \\
\left(\mathrm{g} \cdot \mathrm{m}^{-2}\right)\end{array}$ & WCE & $\begin{array}{c}\text { Mean weed } \\
\text { biomass } \\
\left(\mathrm{g} \cdot \mathrm{m}^{-2}\right)\end{array}$ & WCE & $\begin{array}{c}\text { Mean weed } \\
\text { biomass } \\
\left(\mathrm{g} \cdot \mathrm{m}^{2}\right)\end{array}$ & WCE & $\begin{array}{c}\text { Mean weed } \\
\text { biomass } \\
\left(\mathrm{g} \cdot \mathrm{m}^{-2}\right)\end{array}$ & WCE & $\begin{array}{c}\text { Mean weed } \\
\text { biomass } \\
\left(\mathrm{g} \cdot \mathrm{m}^{-2}\right)\end{array}$ & WCE & $\begin{array}{c}\text { Mean } \\
\text { weed } \\
\text { biomass } \\
\left(\mathrm{g} \cdot \mathrm{m}^{-2}\right)\end{array}$ & WCE \\
\hline Clodinafop-propargyl & $52.5 \mathrm{ml}$ & 92.43 & 67.42 & 334.20 & 23.41 & 426.63 & 40.75 & 130.13 & 66.69 & 445.57 & 20.38 & 575.70 & 39.42 \\
\hline Clodinafop-propargyl & $78.75 \mathrm{ml}$ & 45.23 & 84.06 & 301.73 & 30.85 & 346.97 & 51.81 & 65.03 & 83.35 & 408.67 & 26.98 & 473.70 & 50.15 \\
\hline Clodinafop-propargyl & $105 \mathrm{ml}$ & 9.53 & 96.64 & 285.83 & 34.49 & 295.37 & 58.98 & 17.43 & 95.54 & 379.07 & 32.27 & 396.50 & 58.28 \\
\hline Clodinafop-propargyl $1+A^{*}$ & $52.5 \mathrm{ml}+0.2 \%$ & 19.97 & 92.96 & 297.53 & 31.81 & 317.50 & 55.91 & 31.80 & 91.86 & 395.20 & 29.38 & 427.00 & 55.07 \\
\hline Clodinafop-propargyl + A & $78.75 \mathrm{ml}+0.2 \%$ & 0.00 & 100.00 & 265.57 & 39.14 & 265.57 & 63.12 & 2.77 & 99.29 & 363.37 & 35.07 & 366.13 & 61.47 \\
\hline Clodinafop-propargyl + TO** & $52.5 \mathrm{ml}+0.3 \%$ & 35.40 & 87.52 & 312.07 & 28.48 & 347.47 & 51.75 & 55.63 & 85.76 & 421.60 & 24.66 & 477.23 & 49.78 \\
\hline Clodinafop-propargyl + TO & $78.75 \mathrm{ml}+0.3 \%$ & 2.47 & 99.13 & 284.00 & 34.91 & 286.47 & 60.22 & 6.07 & 98.45 & 384.47 & 31.30 & 390.53 & 58.90 \\
\hline Pyroxsulam & $80 \mathrm{ml}$ & 110.63 & 61.01 & 143.33 & 67.15 & 253.97 & 64.73 & 156.37 & 59.97 & 192.80 & 65.55 & 349.17 & 63.26 \\
\hline Pyroxsulam & $120 \mathrm{ml}$ & 72.87 & 74.32 & 76.37 & 82.50 & 149.23 & 79.28 & 104.40 & 73.28 & 113.03 & 79.80 & 217.43 & 77.12 \\
\hline Pyroxsulam & $160 \mathrm{ml}$ & 25.83 & 90.90 & 25.17 & 94.23 & 51.00 & 92.92 & 38.10 & 90.25 & 37.23 & 93.35 & 75.33 & 92.07 \\
\hline Pyroxsulam +A & $80 \mathrm{ml}+0.2 \%$ & 46.97 & 83.45 & 51.50 & 88.20 & 98.47 & 86.33 & 76.83 & 80.33 & 76.80 & 86.28 & 153.63 & 83.83 \\
\hline Pyroxsulam +A & $120 \mathrm{ml}+0.2 \%$ & 9.03 & 96.82 & 2.53 & 99.42 & 11.57 & 98.39 & 14.47 & 96.30 & 9.97 & 98.22 & 24.43 & 97.43 \\
\hline Pyroxsulam + TO & $80 \mathrm{ml}+0.3 \%$ & 64.67 & 77.21 & 92.37 & 78.83 & 157.03 & 78.19 & 91.30 & 76.63 & 122.30 & 78.15 & 213.60 & 77.52 \\
\hline Pyroxsulam + TO & $120 \mathrm{ml}+0.3 \%$ & 22.67 & 92.01 & 18.87 & 95.68 & 41.53 & 94.23 & 31.10 & 92.04 & 29.67 & 94.70 & 60.77 & 93.61 \\
\hline Tribenurin-methyl & $4 \mathrm{~g}$ & 236.70 & 16.58 & 162.10 & 62.85 & 398.80 & 44.62 & 328.63 & 15.88 & 223.27 & 60.10 & 551.90 & 41.92 \\
\hline Tribenurin-methyl & $6 \mathrm{~g}$ & 231.70 & 18.34 & 103.30 & 76.33 & 335.00 & 53.48 & 316.73 & 18.92 & 147.00 & 73.73 & 463.73 & 51.20 \\
\hline Tribenurin-methyl & $8 \mathrm{~g}$ & 217.93 & 23.19 & 37.20 & 91.47 & 255.13 & 64.57 & 296.07 & 24.22 & 53.23 & 90.49 & 349.30 & 63.24 \\
\hline Tribenurin-methyl +A & $4 \mathrm{~g}+0.2 \%$ & 224.20 & 20.98 & 57.47 & 86.83 & 281.67 & 60.88 & 306.80 & 21.47 & 84.23 & 84.95 & 391.03 & 58.85 \\
\hline Tribenurin-methyl +A & $6 \mathrm{~g}+0.2 \%$ & 208.80 & 26.41 & 8.33 & 98.09 & 217.13 & 69.85 & 293.00 & 25.00 & 14.07 & 97.49 & 307.07 & 67.69 \\
\hline Tribenurin-methyl + TO & $4 \mathrm{~g}+0.3 \%$ & 230.97 & 18.60 & 86.37 & 80.21 & 317.33 & 55.93 & 317.90 & 18.63 & 118.40 & 78.84 & 436.30 & 54.09 \\
\hline Tribenurin-methyl + TO & $6 \mathrm{~g}+0.3 \%$ & 221.47 & 21.95 & 23.27 & 94.67 & 244.73 & 66.01 & 303.83 & 22.23 & 37.03 & 93.38 & 340.87 & 64.13 \\
\hline $\begin{array}{l}\text { Clodinafop-propargyl } \\
+ \text { tribenurin-methyl }\end{array}$ & $52.5 \mathrm{ml}+4 \mathrm{~g}$ & 79.17 & 72.10 & 145.97 & 66.55 & 225.13 & 68.73 & 112.53 & 71.19 & 195.23 & 65.11 & 307.77 & 67.61 \\
\hline $\begin{array}{l}\text { Clodinafop-propargyl } \\
+ \text { tribenurin-methyl }+\mathrm{A}\end{array}$ & $\begin{array}{l}52.5 \mathrm{ml}+4 \mathrm{~g} \\
+0.2 \%\end{array}$ & 15.90 & 94.40 & 43.80 & 89.96 & 59.70 & 91.71 & 29.07 & 92.56 & 65.87 & 88.23 & 94.93 & 90.01 \\
\hline $\begin{array}{l}\text { Clodinafop-propargyl } \\
+ \text { + tribenurin-methyl }+ \text { TO }\end{array}$ & $\begin{array}{l}52.5 \mathrm{ml}+4 \mathrm{~g} \\
+0.3 \%\end{array}$ & 41.77 & 85.28 & 77.33 & 82.28 & 119.10 & 83.46 & 63.03 & 83.87 & 102.63 & 81.66 & 165.67 & 82.57 \\
\hline Hand weeding & Twice & 112.73 & 60.27 & 108.43 & 75.15 & 221.17 & 69.29 & 165.47 & 57.65 & 159.27 & 71.54 & 324.73 & 65.83 \\
\hline Weedy check & -- & 283.73 & 0.00 & 436.33 & 0.00 & 720.07 & 0.00 & 390.67 & 0.00 & 559.63 & 0.00 & 950.30 & 0 \\
\hline L.S.D at $5 \%(1)$ & & 31.36 & & 29.36 & & 51.23 & & 39.69 & & 50.33 & & 75.65 & \\
\hline L.S.D at $5 \%(2)$ & & 29.27 & & 27.49 & & 46.00 & & 46.82 & & 47.35 & & 71.95 & \\
\hline
\end{tabular}

$\mathrm{A}^{*}=$ Argal at $0.2 \%$ v.v. $\quad-\mathrm{TO}^{* *}=$ Techno oil at $0.3 \%$ v.v. $-\quad \mathrm{WCE}=$ weed control efficiency.

(1): L.S.D. of treatments including unweeded control. - (2): L.S.D: of treatments without unweeded control. 
Generally, obtained results revealed that all herbicidal treatments applied either at the recommended rate without adjuvants or at reduced rates with adjuvants significantly decreased fresh weight of grassy, broad-leaved and total weeds in wheat crop as compared with unweeded treatment. Our results are in harmony with (Bhat et al. 2006; Mekky et al., 2007; El-Metwally et al., 2015; Tesfaye et al., 2018 and El-Metwally and Gad, 2019).

In this respect, Bhat et al. (2006) reported that application of clodinafop-propargyl at $0.06 \mathrm{~kg} \mathrm{ha}^{-1}$ effectively controlled $P$. minor and resulted in a significant increase in grain yield compared to unweeded check. Also, Mekky et al. (2007) showed that application of tribenuron, fenoxaprop, isoproturon, bromoxynil + clodinafop-propargyl and hand weeding decreased total weeds and increased grain yield of wheat crop compared to unweeded control. Moreover, El-Metwally et al. (2015) concluded that clodinafop-propargyl was the best option in controlling grassy weeds. Furthermore, El-Metwally and Gad (2019) elucidated that pyroxsulam was the most effective herbicide in reducing dry weight of broadleaved, grasses and total weeds compared with untreated check.

Concerning the mixture of clodinafop-propargyl + tribenuron-methyl, our results indicated that this mixture was effective than clodinafop-propargyl or tribenuron-methyl alone in reducing grassy and broad-leaved weeds. The effectiveness of clodinafop-propargyl + tribenuron-methyl combination might be due to its high selectivity to both grassy and broad-leaved weeds in the wheat crop. These results are conformity with the findings of (Zand et al., 2007; Singh et al., 2008; Aliverdi et al. 2009 and Kumar et al., 2018). In this regard, Zand et al. (2007) concluded that tribenuron methyl plus clodinafop-propargyl showed better-acted treatment than other herbicides on total weeds. However, Singh et al. (2008) recorded that tribenuron-methyl at $15 \mathrm{~g} \mathrm{ha}^{-1}$ was effective as a tank mix application with pinoxaden or clodinafop-propargyl under field conditions. Moreover, Aliverdi et al. (2009) found that the tank mix of clodinafop-propargyl and tribenuron-methyl showed a synergistic effect in controlling wild oat and wild mustard. These results may be due to the inhibitory effect of herbicidal treatments on weeds growth. The high effectiveness of clodinafop-propargyl against annual grassy weeds could be attributed to the high susceptibility of grasses to the herbicidal activity of clodinafop-propargyl in the inhibition Acetyl Co Enzyme Carboxylase (ACCase), the enzyme catalyzing the first committed step in fatty acids synthesis. Inhibition of fatty acid synthesis presumably blocks the production of phospholipids used in building new membranes required for cell growth (WSSA, 1994). Whereas, pyroxsulam and tribenuron-methyl inhibit acetolactate synthase (ALS) enzyme that catalyzes the first common reaction in the biosynthesis of branched-chain amino acids (Vencill, 2002 and Das, 2008).

On the other side, our results indicated that addition of Argal or Techno oil enhanced foliar activity of the herbicide spray solutions. However, Argal was the most effective adjuvant as its addition to the used herbicides at reduced rates led to the highest control of weeds. In general, the used adjuvants in the present investigation allowed reducing herbicide rates to $75 \%$ up to $50 \%$ compared with herbicides without adjuvants. Adjuvants are likely to improve the permeability of the herbicide active ingredient (Johnson et al., 2002) which provides an opportunity to reduce the herbicide application rate (Zabkiewicz, 2000). Tanveer et al. (2014) also reported that addition of adjuvant with reduced herbicide rates resulted in lower total weed density. Our results are in line with findings of (Lu et al., 2005; Aliverdi et al., 2009; Mehdizadeh and Alebrahim, 2015; Rizwan et al., 2018 and Chhokar et al., 2019).

In this regard, Lu et al. (2005) stated that herbicide application rates can be reduced by up to $75 \%$ when applied in combination with adjuvants. The efficacy of tribenuronmethyl increased with surfactant tank-mix against Chenopodium album, Rumex spp. and other broad-leaved weeds (Singh et al., 2008). Aliverdi et al. (2009) reported that the tank 
mix application of tribenuron-methyl and adjuvants has a synergistic effect on weeds in wheat crop. Whereas, Javaid et al. (2012) found that adjuvants increased the efficacy of tribenuron-methyl at reduced rates when compared to recommended rates without adjuvants. On the other side, Stagnari et al. (2006) cited that addition of mineral or vegetable oil could be significantly reduced the application rate of clodinafop-propargyl to $1 / 2$ of the labeled rate to control oats and canarygrass, with no decrease in weed control efficacy.

Furthermore, Rizwan et al. (2018) demonstrated that sunflower oil added to pyroxsulam spray solution caused an increase in control of little seed canary grass and field bindweed control. Furthermore, weed control, particularly of Phalaris minor was significantly poor, when pyroxsulam has applied alone or in combination with sulfosulfuron without surfactant (Chhokar et al., 2019).

Overall, only with an appropriate adjuvant, herbicides can develop their maximum efficacy even at applied at reduced rates than recommended rates. The high effectiveness of the tested herbicides at reduced rates by the two adjuvants may be related to a theory that explains the solubilizing, softening, or disrupting nature of cuticular waxes by adjuvants, allowed a higher amount of active ingredient to penetrate the cuticle rapidly; and accumulate at the site of action where the herbicides act to inhibit weed growth (Hazen, 2000). These processes can improve retention and diffusion of herbicide active ingredient to the more hydrophilic structures under cuticular waxes (Kammler et al., 2010). Moreover, adjuvants can improve herbicide efficacy because they enhance herbicide adhesion to the leaf surface, decrease the surface tension, prolong the droplet drying period and, therefore, allow more of the active ingredient to penetrate into the plant (Aliverdi et al., 2009; Mohassel et al., 2009; Mohassel et al., 2010 and Hammami et al., 2014). It seems that the tested adjuvants led to more cuticular penetration and stomata infiltration and subsequently, allowed better herbicides absorption and translocation (Penner, 2000).

\section{Effect of Herbicidal Treatments on Wheat 1000 Grain Weight:}

The present data in Table (4) demonstrated that 1000-grain weight of wheat (g), was significantly affected by all applied treatments compared to unweeded check during the two studied seasons. As shown in Table (4), pyroxsulam and clodinafop-propargyl applied at different rates with or without Argal or Techno oil adjuvants recorded a maximum increase of 1000-grains weight without significant difference between these treatments. However, the lowest 1000-grain weight was recorded in the weedy check during 2017-2018 and 20182019 seasons. A supporting view was reported by (Harasim et al., 2014; Ali et al., 2016 and Al-Ziady and Shati, 2019) who indicated the importance of the absence of competition during early crop plant growth to improve its quality.

\section{Effect of Herbicidal Treatments on Wheat Straw Yield:}

The obtained data illustrated that the highest straw yield (ton fed. ${ }^{-1}$ ) was recorded with a tank mix of clodinafop-propargyl + tribenuron-methyl combined with Argal adjuvant (5.96 and 5.53 ton fed. ${ }^{-1}$ ), followed by hand weeding twice treatment (5.94 and 5.53 ton fed. ${ }^{-1}$ ) in the both studied seasons, respectively. The minimum straw yield was recorded with the weedy check (4.29 and 3.94 ton fed. ${ }^{-1}$ ) in the both seasons, respectively (Table 4).

\section{Effect of Herbicidal Treatments on Wheat Grain Yield:}

It is obvious from the data listed in Table (4) that the highest increase in wheat grain yield (44.29 and $46.12 \%$ ) was recorded in pyroxsulam treated plots at $3 / 4$ of the recommended rate in combination with Argal during the two studied seasons, respectively, followed by pyroxsulam at $3 / 4$ of recommended rate tank-mixed with Techno oil (43.71 and $45.10 \%$ ), pyroxsulam applied at the full rate without adjuvants (43.12 and $44.93 \%)$ and tank mix of clodinafop-propargyl + tribenuron-methyl combined with Argal adjuvant (42.73 and $43.74 \%$ ) in both studied seasons, respectively. The increasing of wheat grain yield affected by the tested treatments is due to their broad-spectrum weed control. However, the 
weedy check significantly resulted in the lowest grain yield of wheat in the both seasons. Generally, the tested herbicides at their reduced rates (half or $3 / 4$ of recommended rates) in combination with adjuvants effectively controlled weeds in the wheat fields and increased grain yield comparing to the same treatments without the adjuvants. Moreover, the tested herbicides at $3 / 4$ of the recommended rate tank mixed with the two studied adjuvants produced higher wheat grain yield than their full rates without adjuvants.

Table 4: Effect of herbicides and adjuvants on wheat grain yield during 2017-2018 and 2018-2019 winter seasons.

\begin{tabular}{|c|c|c|c|c|c|c|c|c|c|c|c|}
\hline \multirow[b]{2}{*}{ Treatments } & \multirow[b]{2}{*}{ Rate fed..$^{-1}$} & \multicolumn{5}{|c|}{ 2017-2018 } & \multicolumn{5}{|c|}{ 2018-2019 } \\
\hline & & $\begin{array}{l}\text { Grain yield } \\
\left.\text { (ardab fed. }{ }^{-1}\right)\end{array}$ & $\% \mathrm{I}$ & $\begin{array}{c}\text { 1000grain } \\
\text { weight } \\
\text { (g) }\end{array}$ & $\begin{array}{l}\text { Straw yield } \\
\text { (ton fed. }^{-1} \text { ) }\end{array}$ & $\begin{array}{c}\text { Harvest } \\
\text { index }\end{array}$ & $\begin{array}{l}\text { Grain yield } \\
\text { (ardab fed. }^{-1} \text { ) }\end{array}$ & $\% \mathrm{I}$ & $\begin{array}{l}1000 \text { grain } \\
\text { weight }(\mathrm{g})\end{array}$ & $\begin{array}{l}\text { Straw yield } \\
\text { (ton fed. }^{-1} \text { ) }\end{array}$ & $\begin{array}{c}\text { Harvest } \\
\text { index }\end{array}$ \\
\hline Clodinafop-propargy1 & $52.5 \mathrm{ml}$ & 18.44 & 28.31 & 54.73 & 4.70 & 37.06 & 15.49 & 25.25 & 51.70 & 4.17 & 35.77 \\
\hline Clodinafop-propargyl & $78.75 \mathrm{ml}$ & 19.56 & 32.39 & 54.17 & 4.96 & 37.17 & 16.78 & 30.99 & 52.13 & 4.41 & 36.33 \\
\hline Clodinafop-propargy1 & $105 \mathrm{ml}$ & 20.38 & 35.11 & 55.20 & 5.09 & 37.50 & 17.71 & 34.63 & 52.77 & 4.60 & 36.63 \\
\hline Clodinafop-propargy1 $+\mathrm{A}^{*}$ & $52.5 \mathrm{ml}+0.2 \%$ & 20.09 & 34.18 & 55.70 & 5.02 & 37.52 & 17.38 & 33.38 & 53.03 & 4.52 & 36.57 \\
\hline Clodinafop-propargy1 + A & $78.75 \mathrm{ml}+0.2 \%$ & 20.84 & 36.57 & 55.90 & 5.12 & 37.90 & 18.18 & 36.31 & 53.10 & 4.70 & 36.70 \\
\hline Clodinafop-propargy $1+\mathrm{TO}^{* * *}$ & $52.5 \mathrm{ml}+0.3 \%$ & 19.51 & 32.23 & 55.23 & 4.93 & 37.25 & 16.64 & 30.44 & 52.17 & 4.35 & 36.48 \\
\hline Clodinafop-propargy1 + TO & $78.75 \mathrm{ml}+\mathrm{O}$ & 20.51 & 35.54 & 55.53 & 5.10 & 37.63 & 17.96 & 35.52 & 52.63 & 4.69 & 36.48 \\
\hline Pyroxsulam & $80 \mathrm{ml}$ & 20.36 & 35.04 & 55.07 & 5.11 & 37.42 & 18.04 & 35.84 & 51.93 & 4.58 & 37.14 \\
\hline Pyroxsulam & $120 \mathrm{ml}$ & 21.84 & 39.47 & 55.10 & 5.40 & 37.76 & 19.31 & 40.05 & 52.33 & 4.87 & 37.28 \\
\hline Pyroxsulam & $160 \mathrm{ml}$ & 23.24 & 43.12 & 55.33 & 5.64 & 38.19 & 21.02 & 44.93 & 52.47 & 5.21 & 37.71 \\
\hline Pyroxsulam + A & $80 \mathrm{ml}+0.2 \%$ & 22.53 & 41.32 & 55.70 & 5.43 & 38.38 & 19.80 & 41.53 & 53.00 & 4.93 & 37.60 \\
\hline Pyroxsulam +A & $120 \mathrm{ml}+0.2 \%$ & 23.73 & 44.29 & 55.83 & 5.70 & 38.45 & 21.49 & 46.12 & 52.97 & 5.33 & 37.67 \\
\hline Pyroxsulam + TO & $80 \mathrm{ml}+0.3 \%$ & 21.80 & 39.35 & 55.50 & 5.36 & 37.90 & 19.29 & 39.98 & 52.57 & 4.83 & 37.44 \\
\hline Pyroxsulam + TO & $120 \mathrm{ml}+0.3 \%$ & 23.49 & 43.71 & 55.70 & 5.67 & 38.31 & 21.09 & 45.10 & 52.73 & 5.28 & 37.47 \\
\hline Tribenuron-methyl & $4 \mathrm{~g}$ & 18.11 & 26.99 & 51.87 & 5.43 & 33.33 & 15.36 & 24.60 & 47.30 & 4.74 & 32.69 \\
\hline Tribenuron-methy1 & $6 \mathrm{~g}$ & 19.51 & 32.23 & 52.00 & 5.69 & 33.97 & 16.53 & 29.97 & 48.23 & 4.98 & 33.24 \\
\hline Tribenuron-methy1 & $8 \mathrm{~g}$ & 20.42 & 35.26 & 52.07 & 5.84 & 34.41 & 17.89 & 35.28 & 48.33 & 5.34 & 33.43 \\
\hline Tribenuron-methy1 + A & $4 \mathrm{~g}+0.2 \%$ & 20.18 & 34.47 & 52.40 & 5.77 & 34.41 & 17.31 & 33.12 & 48.77 & 5.15 & 33.54 \\
\hline Tribenuron-methy1 + A & $6 \mathrm{~g}+0.2 \%$ & 21.07 & 37.24 & 52.57 & 5.89 & 34.93 & 18.36 & 36.92 & 49.10 & 5.41 & 33.74 \\
\hline Tribenuron-methy $1+\mathrm{TO}$ & $4 \mathrm{~g}+0.3 \%$ & 19.58 & 32.46 & 51.93 & 5.67 & 34.12 & 16.82 & 31.18 & 48.33 & 5.02 & 33.44 \\
\hline Tribenuron-methy1 + TO & $6 \mathrm{~g}+0.3 \%$ & 20.76 & 36.30 & 52.40 & 5.86 & 34.71 & 17.93 & 35.44 & 48.83 & 5.35 & 33.45 \\
\hline $\begin{array}{l}\text { Clodinafop-propargy1 } \\
+ \text { Tribenuron-methy1 }\end{array}$ & $52.5 \mathrm{ml}+4 \mathrm{~g}$ & 20.62 & 35.88 & 54.10 & 5.44 & 36.24 & 18.38 & 37.00 & 51.33 & 5.08 & 35.16 \\
\hline $\begin{array}{l}\text { Clodinafop-propargy1 + } \\
\text { Tribenuron-methy1 + A }\end{array}$ & $\begin{array}{l}52.5 \mathrm{ml}+4 \mathrm{~g} \\
+0.2 \%\end{array}$ & 23.09 & 42.73 & 55.07 & 5.96 & 36.77 & 20.58 & 43.74 & 52.00 & 5.53 & 35.84 \\
\hline $\begin{array}{l}\text { Clodinafop-propargy1 + } \\
\text { Tribenuron-methy1 + TO }\end{array}$ & $\begin{array}{l}52.5 \mathrm{ml}+4 \mathrm{~g} \\
+0.3 \%\end{array}$ & 22.40 & 40.97 & 54.50 & 5.84 & 36.51 & 19.71 & 41.26 & 51.87 & 5.34 & 35.64 \\
\hline Handweeding & twice & 20.40 & 35.19 & 50.63 & 5.94 & 33.98 & 18.36 & 36.92 & 47.33 & 5.53 & 33.24 \\
\hline Weedy check & $-\ldots$ & 13.22 & 0.00 & 46.70 & 4.29 & 31.58 & 11.58 & 0.00 & 44.40 & 3.94 & 30.58 \\
\hline L.S.D at $5 \%(1)$ & & 0.970 & & 2.2479 & 0.220 & 0.559 & 0.921 & & 2.656 & 0.241 & 0.418 \\
\hline L.S.D at $5 \%(2)$ & & 0.917 & & 2.2470 & 0.201 & 0.553 & 0.896 & & 2.698 & 0.235 & 0.351 \\
\hline
\end{tabular}

$\mathrm{A}^{*}=$ Argal at $0.2 \%$ v.v. $\quad-\mathrm{TO}^{* *}=$ Techno oil at $0.3 \%$ v.v. (1): L.S.D. of treatments including unweeded control. - (2): L.S.D: of treatments without unweeded control

The higher grain and straw yield could be attributed to the higher weed control efficiency, hence the competition ability of weeds was poor which gave a competitive advantage to the wheat plants in utilizing the necessary demands of nutrients and water, leading to increasing the wheat growth resulted in the higher grain and straw yield as well as the crop index. On contrary, the reduction in wheat grain yield in weedy check may be due to the competition with weed plants for nutrients, water, sunlight and space.

The increases in grain and straw yield may be due to minimizing weed-wheat competition. Similar results are reported by (Marzouk, 2013; Salim et al., 2017; Chhokar et al., 2019 and El-Metwally and Gad, 2019). In this respect, Salim et al. (2017) cited that Granstar + Topic recorded maximum plant height, spike length, number of grains per spike and grain yield of wheat, however, 1000 grain weight and number of plants $\mathrm{m}^{2}$ were noted with Atlantis followed by Granstar + Topic. However, El-Metwally and Gad (2019) found that applying pyroxsulam resulted in increases in the number of spikes $\mathrm{m}^{2}$, straw and grain yields by 34.2, 37.6 and $45.3 \%$ over the weedy control, respectively. Knezevic et al. (2010) and Tagour et al. (2011) indicated that the application of herbicides with adjuvants caused an increase in yield in comparison with plots treated with herbicide without adjuvants. Tagour et al. (2011) reported that Traxos at $500 \mathrm{~cm}^{3}$ and Topik at $140 \mathrm{~g}$ tank-mixed with adjuvant at 4 and $8 \%$ gave the highest values of grain yield fed. ${ }^{-1}$ while the lowest values of 
the grain yield were recorded with Topik at $140 \mathrm{~g}$ alone and Traxos at $500 \mathrm{~cm}^{3}$ alone after unweeded control in both seasons.

\section{Effect of herbicidal treatments on harvest index:}

Data concerned with the effect of weed control treatments on harvest index are expressed in Table (4). It is clear that all herbicidal treatments increased harvest index \% over unweeded check during the two studied seasons. However, pyroxsulam followed by clodinafop-propargyl and mixture of clodinafop-propargyl + tribenuron-methyl significantly was the best in increasing the harvest index compared to unweeded check during 2017-2018 and 2018-2019 seasons. These outcomes agree with the findings of Harasim et al. (2014) explained that the use of herbicides leads to an inevitable increase in harvest index in the treatment of herbicides.

\section{Conclusion:}

From the previous results, it could be concluded that addition of adjuvants such as Argal at $0.2 \%$ or Techno oil at $0.3 \%$ to reduced herbicides rates especially at $3 / 4$ of the recommended rate resulted in enhancing the herbicidal activity against weeds, increasing grain yield of wheat, decreasing environmental pollution and achieved higher net benefitratio compared to the recommended rates.

\section{REFERENCES}

Abd-El-Haleem, S.H.M.; M.A. Reham; S.M.S. Mohamed; E.S.M. Abdel-Aal; F.W. Sosulski and P. Huc (1998). Origins, characteristics and potentials of ancient wheats. Cereal Foods World, 43: 708-715.

Abdel-Hamid, M.M.A.; E.E. Hassanein and S.M. Shebl (1998). Weed/wheat competition in Nile delta. Assiut. Journal of Agricultural Sciences, 29:105-13.

Abouziena, H.F.; A.A. Sharara, Faida and E.R. El-Desoki (2008). Efficacy of cultivar selectivity and weed control treatments on wheat yield and associated weeds in sandy soils. World Journal of Agricultural Sciences, 4 (3): 384-389.

Adams, M.L.; E. Lombi; F.J. Zhao and S.P. McGrath (2002). Evidence of low selenium concentrations in UK bread-making wheat grain. Journal of the Science of Food and Agriculture, 82: 1160-1165.

Ali, K.A.; M.H. Qadir; S.O. Rasoul and S.S. Ali (2016). Physiological and Yield Responses of Wheat (Triticum aestivum) to Different Herbicide Treatments. Journal of Zankoi Sulaimani, Part-A- (Pure and Applied Sciences).

Aliverdi, A.; M.H.R. Mohassel and M. Mahallati (2009). Increased foliar activity of clodinafop-propargyl and/or tribenuronmethyl by surfactants and their synergistic action on wild oat (Avena ludoviciana) and wild mustard (Sinapis arvensis). Weed biology and management, 9: 292-299.

Al-Ziady, S.H. and R.K. Shati (2019). Effect of six herbicides to control the wild barley and other weeds accompanied with wheat. In IOP Conference Series: Earth and Environmental Science, 388(1): p. 012039.

Bhat, M.A.; S.S. Mahal; A. Hussain and G.M. Mushki (2006). Effect of nitrogen levels, irrigation regimes and weed management in durum wheat (Triticum durum Desf.). Indian Journal of Crop Science, 1(1-2):184-188.

Chhokar, R. S.; R.K. Sharma; S.C. Gill and R.K. Singh (2019). Broad spectrum weed control in wheat with pyroxsulam and its tank mix combination with sulfosulfuron. Journal of Cereal Research, 11(1): 27-36.

Das, T.K. (2008). Weed science basics and applications (pp. 1-901). New Delhi: Jain Brothers. 
El-Metwally, I.M. and N. Gad (2019). Wheat productivity and water use efficiency responses to irrigation, cobalt and weed management. Italian Journal of Agrometeorology, (1): 13-24.

El-Metwally, I.M.; O.A. Ali and M.T. Abdelhamid (2015). Response of wheat (Triticum aestivum L.) and associated grassy weeds grown in salt-affected soil to effects of graminicides and indole acetic acid. Agriculture (Pol'nohospodárstvo), 61(1): 1-11.

Gomez, K.A. and A.A. Gomez (1984). Statistical Procedures for Agriculture Research. A Wiley - Inter Science Publication, John Wiley \& Sons, Inc., New York, USA.

Hammami, H.; A. Aliverdi and M. Parsa (2014). Effectiveness of clodinafop-propargyl, haloxyfop-p-methyl and difenzoquat-methyl-sulfate plus Adigor ${ }^{\circledR}$ and Propel $^{\mathrm{TM}}$ adjuvants in controlling Avena ludoviciana Durieu. Journal of Agricultural Science and Technology, 16: 291-299.

Harasim E.; M. Wesołowski and C. Kwiatkowski (2014). The effect of reduced growth retardant rate on weed infestation of a winter wheat (Triticum aestivum L.) crop. Romanian Agricultural Research, 31:1-11.

Hazen, J.L. (2000). Adjuvants terminology, classification and chemistry. Weed Technology, 14: 773-784.

Javaid, M.M.; A. Tanveer; R. Ahmad; M. Yaseen and A. Khaliq (2012). Optimizing activity of herbicides at reduced rate on Emex spinosa campd with adjuvants. Planta daninha, 30(2): 425-435.

Javaid, M.M.; A.U.H. Zia; H. Waheed; J. Nargis; A. Shahid; A. Aziz and A. Wasaya (2020). Effect of isoproturon with and without adjuvants on photosynthetic attributes of wheat and its associated weeds. Planta Daninha, 38. https://doi.org/10.1590/s010083582020380100024

Johnson, H.E.; J.L. Hazen and D. Penner (2002). Citric ester surfactants as adjuvants with herbicides. Weed Technology, 16: 867-872.

Kammler, K.J.; S.A. Walters and B.G. Young (2010). Effects of Adjuvants, Halosulfuron, and Grass Herbicides on Cucurbita spp. Injury and Grass Control. Weed Technology, 24: $147-152$.

Khaliq A.; A. Matloob; A. Tanveer; A. Areeb, F. Aslam and N. Abbas (2011). Reduced doses of a sulfonylurea herbicide for weed management in wheat fields of Punjab, Pakistan. Chilean journal of agricultural research, 71: 424-429.

Knezevic, S.Z.; A. Datta; J. Scott and L.D. Charvat (2010). Application timing and adjuvant type affected saflufenacil efficacy on selected broadleaf weeds. Crop Protection, 29 (1): 94-99.

Kumar, M.; .R. Kishore; S. Kumar and S. Bisht (2018). Efficacy of different post-emergence herbicides application alone and in combination in wheat. Journal of Pharmacognosy and Phytochemistry; SP1: 1668-1670.

Kumar, S.; N.N. Angiras and S.S. Rana (2011). Bio-efficacy of clodinafop-propargyl + metsulfuron-methyl against complex weed flora in wheat. Indian Journal of Weed Science, 43(3, 4):195-198.

Kumar, S.; N.N. Angiras; S.S. Rana and N. Sharma (2009). Alternative methods of isoproturon application in wheat. Himachal Journal of Agricultural Research, 35(1):31-33.

Lu, M.; W. Jinxin; W. Liping; L. Yuzhu; L. Wei and L. Haitao (2005). A study on the synergistic effects of methyl oleate adjuvants on herbicides and their safety on maize seedlings. Plant Protection, 31(5): 83-85.

Mahmoud, S.M.; F.S. Soliman and M. Elsheik (2016). Combination of halauxifen -methyl + florasulam with other grassy herbicides against complex weed flora in wheat 
(Triticum aestivum). Journal of Plant Protection and Pathology, Mansoura University, 7(5), 315-320.

Mani, V.S.; M.L. Malla; K.C. Gautam; and Bhagwndas (1973). Weed killing chemicals in potato cultivation. Indian Farming, VXXII: 17-18.

Marzouk, E.M.A. (2013). Chemical Weed Control in Wheat (Triticum aestivum L.). Journal of Applied Sciences Research, 9(8): 4907-4912.

Mehdizadeh, M. and M.T. Alebrahim (2015). Effect of some adjuvants application on enhancing sulfosulfuron herbicide performance. Azarian Journal of Agriculture, 2 (1): 7-11.

Mekky, M.S.; M.A. Ali and S.A. Elmajeed (2007). Effect of mechanical tillage system, wheat varieties and weed control treatments on wheat (Triticum aestivum L.) productivity. Misr Journal of Agricultural Engineering, 24(1): 18-41.

Mohassel, M.H.R.; A. Aliverdi and R. Ghorbani (2009). Effects of a magnetic field and adjuvant in the efficacy of cycloxydim and clodinafop-propargyl on the control of wild oat (Avena fatua). Weed biology and management, 9(4): 300-306.

Mohassel, M.H.R.; A. Aliverdi; H. Hamami and E. Zand (2010). Optimizing the performance of diclofop-methyl, cycloxydim, and clodinafop-propargyl on littleseed canarygrass (Phalaris minor) and wild oat (Avena ludoviciana) control with adjuvants. Weed biology and management, 10(1): 57-63.

Mukherjee, I.; T.K. Das; A. Kumar; B. Sarkar and K.K. Sharma (2015). Behavior and bioefficacy of tribenuron-methyl in wheat (Triticum astevum L.) under irrigated agro-ecosystem in India. Environmental monitoring and assessment, 187(10): 610.

Penner D. (2000). Activator adjuvants. Weed Technology, 14: 785-791.

Rizwan, M.; A. Tanveer; A. Khaliq; T. Abbas and N.A. Ikram (2018). Increased foliar activity of isoproturon+ tribenuron and pyroxsulam against little seed canary grass and field bindweed by proper adjuvant selection in wheat. Planta Daninha, 36. http://dx.doi.org/10.1590/s0100-83582018360100024

Salim, H.A.; A.A. Abdalbaki; H.A. Khalid; A.S. Taha and S.F. Dawood (2017). Evaluation of herbicidal potential of commercial herbicides in wheat (Triticum aestivum L.) cultivation. Recent Research in Science and Technology, 9: 10-12.

Sharma, A.R.; M.S. Bhullar; V.P. Singh; M. Singh and T.K. Das (2016). Harnessing weedfertilizer-water interactions for higher crop productivity and resource-use efficiency. Indian Journal of Fertilizers, 12(11): 114-130.

Sharma, J.; S.S. Tomar; A. Singh; R.L. Rajput and S. Singh (2018). Effect of fertility levels and weeds management practices on weeds dynamics, yield and economics of wheat (Triticum aestivum L.). Journal of Pharmacognosy and Phytochemistry, SP2: 25-28.

Shewry, P.R. (2009). The health grain programme opens new opportunities for improving wheat for nutrition and health. Nutrition Bulletin, 34(2): 225-231.

Singh, S.; S.S. Punia; R.S. Balyan and R.K. Malik (2008). Efficacy of tribenuron-methyl applied alone and tank mix against broadleaf weeds of wheat (Triticum aestivum L.). Indian Journal of Weed Science, 40(3and4): 109-120.

Soliman, I. S. and A. M. Hamza (2015). Effect of some herbicides on wheat characters and associated weeds with respect to its residues. Egypt Journal of Plant Protection Research, 3(4): 29-47.

Stagnari, F., A. Onofri and G. Covarelli (2006). Influence of vegetable and mineral oils on the efficacy of some post-emergence herbicides for grass weed control in wheat. Journal of Pesticide Science, 31(3), 339-343.

Tagour, R.M.H., G.M El-Hamed and I.M. EL-Metwally, (2011). Improving herbicides efficacy of Topik and Traxos on wheat plants and associated weeds by adjuvants Arkopal. Nature and Science, Vol. (9), No.11, pp. 176- 183. 
Tanveer, A.; A. Khalid; M. Tahir and M.A. Nadeem (2014). Effect of tank mixed application of ammonium sulphate and carfentrazone-ethyl+ clodinafop-propargyl+ metsulfuron-methyl on weeds and yield of wheat. Biological Sciences-PJSIR, 57(3): 117-122.

Tesfaye, Y.; O. Chimdesa; K. Asefa and G. Teshome (2018). Evaluation and demonstration of different post-emergence herbicides for controlling wild oat (Avena fatua L.) and other grass weeds in wheat (Triticum Spp) at Bore. Agricultural Research and Technology: Open Access Journal, 16(4). 555992.

Vencill, W. K. (2002). Herbicide handbook (eighth ed., p. 493). Lawrence: Weed Science Society of America.

WSSA (Weed Science Society of America), (1994). Herbicide Handbook $7^{\text {th }}$ Ed. Champaign, lllinois, USA.

Zabkiewicz, J.A. (2000). Adjuvants and herbicidal efficacy present status and future prospects. Weed Research, 40: 139-149.

Zaki, M.A. (2000). Identification and control of important weed in Egypt pp 266 Al-Ahram Commerial Press. Kalyoub-Egypt.

Zand, E.; M.A. Baghestani; S. Soufizadeh; A. Eskandari; R. PourAzar; M. Veysi and A. Barjasteh (2007). Evaluation of some newly registered herbicides for weed control in wheat (Triticum aestivum L.) in Iran. Crop Protection, 26(9): 1349-1358. 